\title{
RX for Success: Former MinuteClinic CEO Linda Hall Shares her Stories
}

\author{
Daniel Forbes (University of Minnesota) \\ Linda Hall (University of Minnesota)
}

KEYWORDS: Management of Companies \& Enterprises, Health Care \& Biotech, Entrepreneurship, Finance, Leadership, Women, Learn From Leaders.

In 2002, both Linda Hall and her new company -- which would later become MinuteClinic, a fixture in 1000 CVS stores -- had a lot to lose. Hall was the sole breadwinner in her household and had no nest egg, and the company was similarly at the end of its rope financially. Through tenacity, a thick skin and an outsider's fresh perspective, Hall helped her company gain the financing it needed to grow, and eventually be feted by the World Economic Forum for its innovative healthcare delivery. In an interview with Dan Forbes, Hall shares lessons from her teenage years selling Michigan cherries, her early career in education and the roadblocks she faced as an entrepreneur.

\section{Read More:}

Advice, Best Practices and Inspiration for Women Entrepreneurs(https://eiexchange.com/women)

Additional search terms: women, feminism, female founders, women business owners, glass ceiling, finding financing, getting money for my new business, finding investors, bias, opportunity 